\title{
VIOLENCE IN THE VIEW OF YOUNG PEOPLE IN THE PERSPECTIVE OF CORPOREALITY AND VULNERABILITY
}

\author{
Elisangela Argenta Zanattaํ, Maria da Graça Corso da Motta²
}

\footnotetext{
${ }^{1}$ Ph.D. in Nursing. Professor of the Department of Nursing of the Universidade do Estado de Santa Catarina. Chapecó, Santa Catarina, Brazil. E-mail: elisangela.zanatta@udesc.br

${ }^{2}$ Ph.D. in Nursing. Professor of the Universidade Federal do Rio Grande do Sul. Porto Alegre, Rio Grande do Sul, Brazil. E-mail: mottinha@enf.ufrgs.br
}

\begin{abstract}
The aim was to understand how violence is understood by the young, in their experience, in the perspective of corporeality and vulnerability. Qualitative research was undertaken with 21 young people, students of nursing at a university in the West of the Brazilian state of Santa Catarina. The information was produced based on a genogram and ecomap, and on the dynamics of creativity and sensitivity, these being interpreted in the light of Hermeneutics. The young understand violence as an absence of happiness, as something which harms their integrity; by violence, they understand the negligence existing in the relationship between parents and children and in the conflictual relationships experienced in the family. The study raised important elements for understanding the violence from the viewpoint of the young person, revealing the need to outline actions of nursing care which reduce the situations of vulnerability to this phenomenon which interferes in their way of being in the world.
\end{abstract}

DESCRIPTORS: Violence. Young people. Vulnerability in health. Nursing.

\section{VIOLÊNCIA, SOB O OLHAR DE JOVENS, NA PERSPECTIVA DA CORPOREIDADE E DA VULNERABILIDADE}

RESUMO: Objetivou-se entender de que modo a violência é compreendida pelos jovens, no seu vivido, na perspectiva da corporeidade e da vulnerabilidade. Pesquisa qualitativa, realizada com 21 jovens, acadêmicos de enfermagem de uma universidade do Oeste catarinense. As informações foram produzidas a partir do genograma e ecomapa e das dinâmicas de criatividade e sensibilidade, sendo interpretadas à luz da Hermenêutica. Os jovens entendem a violência como ausência de felicidade, como algo que fere a sua integridade; compreendem por violência a negligência existente na relação entre pais e filhos e nas relações conflituosas vivenciadas na família. A pesquisa trouxe elementos importantes para entender a violência pela ótica do jovem, revelando a necessidade de traçar ações de cuidado de enfermagem que diminuam as situações de vulnerabilidade a esse fenômeno que interfere no seu modo de ser no mundo. DESCRITORES: Violência. Jovens. Vulnerabilidade em saúde. Enfermagem.

\section{VIOLENCIA SOBRE EL PUNTO DE VISTA DE LOS JOVENES EN LA PERSPECTIVA DE LA CORPOREIDAD Y VULNERABILIDAD}

RESUMEN: Se busco entender de qué modo la violencia es comprendida por los jóvenes en sus experiencias en la perspectiva de la corporeidad y de la vulnerabilidad. Investigación cualitativa, realizada con 21 jóvenes, académicos de enfermería de una universidad del Oeste catarinense. Las informaciones fueron producidas a partir del genograma y ecomapay de las dinámicas de creatividady sensibilidad, siendo interpretadas a la luz de la Hermenéutica. Los jóvenes entienden a la violencia como ausencia de felicidad, como algo que hiere su integridad; comprenden por violencia la negligencia existente en la relación entre padres e hijosyen las relacionesconflictivasvividasen la familia. La investigación trajo elementos importantes para entender la violencia en la óptica del joven, revelando la necesidad de trazar acciones de cuidado de enfermería que disminuyanlas situaciones de vulnerabilidad a ese fenómeno que interfiere ensu modo de ser en el mundo.

DESCRIPTORES: Violencia. Jóvenes. Vulnerabilidad en salud. Enfermería. 


\section{INTRODUCTION}

The violence observed and experienced in the current setting in Brazil is not something new; it has accompanied humanity throughout its existence, causing negative impacts in the individual and collective ambits. It is interpreted, however, from different perspectives in each country, culture and society. Violence is inherent to society; it is multidimensional, considered a serious public health problem, and is the result of relationships of communication, conflict and power; there are no societies without violence, and there are societies which are more and less violent, each with its own history and particular forms of violence. ${ }^{1}$

In the contemporary context, emphasis is placed on the close relation between youth and violence, evidenced in the statistics which describe its panorama. The highest rates of mortality from external causes are in the group aged between 15 and 24 years old. ${ }^{2}$ These data support what scholars of the area of epidemiology call epidemiological transition $\square$ the infectious illnesses give way to the chronic illnesses, degenerative illnesses, and to harm caused by accidents and violence. ${ }^{1}$

In the light of this scenario, one can say that due to the fact that young people are exposed to different types of external violence, "the fruit of socioeconomic inequality, or inserted in the context permeated by imposed or self-inflicted risks, configured as a period of life of extreme vulnerability" .3:463

Vulnerability is related to the chance that an individual has of being exposed to a specific event and becoming ill; it is the result of a set of aspects of an individual, collective and contextual order, which entail greater or lesser susceptibility to infection and to illness and, simultaneously, to the possibility of resources for their confrontation. Vulnerability can therefore be defined as a conceptual synthesis of the individual, social and programmatic dimensions which are relevant to prevention or reduction of harms or shortcomings in health. ${ }^{4}$

The terms of harm or shortcomings, present in the concept, can be specified as situations of violence, which may, therefore, be addressed as "an articulated set of individual, social and programmatic aspects which expose to the problem and, at the same time, to the concrete possibilities for defending against it". $5: 63$ That is to say, specific situations of violence, to which the young people are exposed or to which they expose themselves, can generate situations of vulnerability visualized in three dimensions - individual, social and programmatic. $^{4}$

The individual component takes into account the young person's knowledge regarding a specific form of harm, her ability to elaborate information or incorporate it into her concerns, and the interest in transforming these concerns into protective practices. The social component integrates the social dimension, and relates to access to information and the ability to understand it so as to incorporate it into practical changes in everyday life. ${ }^{4}$ The young person, in having access to the information, is able to understand that some experiences in her routine can expose her to situations of violence in different ambits: in the family, on the street, at school and in leisure spaces.

The programmatic component encompasses the degree and quality of the Government's commitment in the planning, implantation, implementation and monitoring of policies, programs, and preventive, educational and care actions. It is also related to access to the health services, to the bond between professionals and service users, and to the resources existing for the continuity and sustainability of the actions. ${ }^{6}$ The vulnerability perceived, in these three planes, indissociably, becomes even greater when the violence is present in the world experienced by the young person, interfering in her corporeality and way of being.

Corporeality is expressed by the body which feels and is felt, sees and is seen, touches and is touched. It is humanity's way of being. ${ }^{7}$ As a corporeal being, the young person constructs her experiences in the world, in particular, because she is experiencing rapid and numerous changes which define her existence. At specific times, however, she may face conflictual situations of affirmation with herself, with her family and with society, which can place her in situations of vulnerability to violence.

In addition to identifying violence in its multiple aspects, it is understood that it is important to understand this phenomenon as it is conceptualized by young people, as this may help in addressing each situation, thus helping the nursing and health professionals to recognize the signs of violence, whether these are visible or masked by behaviors of rebellion or isolation.

With this aim, elements were sought in the national and international literature which could help to understand this phenomenon from the young person's perspective. It stands out, how- 
ever, that in the databases researched and in the studies selected, studies were not found which had been undertaken with the aim of understanding violence from the viewpoint of young people or with results which made it possible to understand how they perceive it and what they think about the violence present in their routine, and how it can interfere in their way of being in the world.

The results of the studies selected made it possible to infer that to think about violence from the perspective of young people is a difficult task. This may be why it is studied little. The situation justified the undertaking of this study, which aimed to understand how violence is understood by the young, in their experience, in the perspective of corporeality and vulnerability.

\section{METHODS}

This is exploratory and descriptive research, with a qualitative investigation approach. It was undertaken in 2013, with 21 students of nursing, in a university located in the municipality of Chapecó, Santa Catarina. The inclusion criteria were: to be aged between 15 and 24 years old and to be studying in the first and/or eighth phase of the Undergraduate Course in Nursing in the university selected as the research scenario at the time of data collection. Following the project's approval by the competent bodies, a meeting was held with the group of the first phase, and another with the group of the eighth phase, of the Undergraduate Course in Nursing, in order to speak about the study, its objectives, and information collection methodology, and to invite those interested to participate.

At this point, the group of the first phase was made up of 30 people, and that of the eighth phase, by 18 . Out of a total of 48 young people, 21 showed interest in participating. The others explained that they were in a period with assessments and academic work, a situation which would make it difficult for them to participate at all points. Hence, 21 young people participated in the study, aged between 17 and 23 years old, originating from various regions of the States of Santa Catarina and Río Grande do Sul, being constituted in two groups: one group of 10 young people who were in the first phase, and the other with 11 young people in the eighth phase.

The production of the information was put into effect in three meetings with each group. Initially, the meetings were held with the young people of the first phase (Group 1), and, later, with those of the eighth phase (Group 2), maintaining the same script for each meeting with both groups. In the first meeting, the genogram and ecomap were constructed, components of the Calgary Family Assessment Model. ${ }^{8}$ This strategy was used with the aim of getting to know each young person in their family and social context, and the effects of violence in the world they experienced. These instruments have been "used by Brazilian nursing as complementary tools in the collection of data in research", 9:218 as they favor the identification of vulnerabilities, assisting in the planning of healthcare actions. ${ }^{9}$

In the second and third meetings, the dynamics of creativity and sensitivity (DCS) were held, stipulated by the Creative Sensitive Method (MCS). ${ }^{10}$ Each meeting lasted for an average of 90 minutes. This method seeks to shed light on a research question which is defined by the researcher and subsequently reoriented by the collective discussions in the group. For this, it privileges collective participation and valorizes everything which emerges from the participants' thinking and perception. ${ }^{10}$

In order to fully undertake each meeting, five points are necessary: "preparation of the environment and embracement of the group; presentation of the group participants; explanation of the dynamic and individual or collective work; presentation of the productions; and collective analysis and validation of the data" ${ }^{10: 132}$ It is emphasized that in this study, the MCS was used only as a strategy for collecting information, the stages of collective analysis and validation not, therefore, being used.

The information was interpreted in the light of Paul Ricoeur's Hermeneutics, ${ }^{11}$ in four stages: 1) Initial reading: in transcribing the participants' accounts, the spoken text was transformed into written text, it being necessary to organize it. For this, numerous readings were undertaken without judgment, with the aim of grasping the meanings which emerged from the accounts in order, in this way, to organize them. ${ }^{11-12} 2$ ) Reflexive reading: in this stage, an in-depth reading of the text was undertaken. ${ }^{11}$ For this, reading was begun with the phrase, followed by the paragraph, followed by the text in full, with the aim of interpreting and understanding the probable meanings present in the text, that is, to identify in them the open and hidden meaning. ${ }^{11-12}$ 3) Identification of the metaphor: in this stage, the hermeneutic interpretation took place, that is, the point at which the researcher 
managed to understand the essence of the young peoples' experience in relation to violence..$^{11} 4$ ) Appropriation: this took place when the researcher succeeded in understanding and assimilating the meanings of each message, allowing to become known what had until then been unknown. ${ }^{11}$ This is the point at which the meanings of the discourses became more visible, for responding to the research question: how do young people understand the situations of vulnerability to violence in their experience, and what are this phenomenon's repercussions in their corporeality?

Approval was obtained from the Research Ethics Committee of the Universidade Federal do Rio Grande do Sul, in accordance with Resolution 466/2012, CAAE: 02870012.8.0000.5347. Those young people over 18 years old were requested to sign the terms of free and informed consent, while for those under 18, this was signed by their parents, and the young people signed the terms of consent.

\section{RESULTS AND DISCUSSION}

The analysis of the participants' genograms and ecomaps made it possible to evidence that a significant number of young people experience conflictual relationships in the family context, especially between the parents, or between the young person with the father and/or stepfather and stepmother.

In the majority of the families reconstituted by one of the parents following the process of separation, the young people emphasize conflictual relationships with the stepfather. In the families in which the father is an alcoholic, the mother, generally, establishes a strong bond with her work, which in some families leads to a moderate bond with the young person. Through this, one can observe family environments which are weakened, in particular by the lack of dialogue between parents and children, strengthening the young person's vulnerability, especially in the individual and social planes.

In the DCSs, the young people reproduced - through pictures, cuttings, collages and textual productions - their understanding on violence, and subsequently socialized their production with the other participants. When asked about the types of violence which they knew and in which places they occur, they highlighted in first place violence of a physical and psychological nature (verbal and power relations), followed by sexual violence, neglect, discrimination, social and moral violence and overprotection. They mention child labor, prejudice, racism, and gender violence. They confirm that these types of violence occur mainly in leisure spaces, in the family, at school and at work.

Based on the young people's production, explanation and discussion in each DCS, discourses were extracted which made it possible to identify how the young people understand the violence. These were grouped in three themes and were subsequently discussed and explored based on the framework of vulnerability and of corporeality.

\section{Violence [...]: the opposite path to happiness}

In their discourses, the young people stated that violence accompanies their existence in all the contexts and places which they frequent. It is part of their routine. One can observe, however, that each one understands it differently, based on their experiences, their culture, their history and their way of being and living. However, the majority relate violence to absence of happiness. for us, violence is the opposite path to happiness [...]. Happiness would be the search for these dreams, and the violence interrupts this search (Young persons 11 and 16).

The word "happiness", in a sense, is frequently associated with expressions of well-being and quality of life. It has a direct relation to opportunities which the person has for enjoying a good life, and this involves internal elements, inherent to each one, and external elements related to nature. ${ }^{13}$

The conquest of happiness is different for each one. Each young person has a perception of what he or she needs for achieving happiness, as the act of perceiving always occurs based on a certain perspective, on a specific point of view. Each one perceives the world with a meaning, as it is not an object of abstract thinking, but rather, the place where each one lives, moves and reacts emotionally to specific situations with a view to changing it. All these interactions with the world give rise to its signification. ${ }^{7}$

Happiness has specific meaning for each young person, depending on each one's interest and involvement with the world and with the people with whom she co-exists. The meaning attributed by the young person to the world is based on her experiences, as perception is related to the corporeal attitude, an experience of existence; it is related to the body in movement. ${ }^{7}$ 
The discourses below reinforce the understanding that violence interferes with or stops the young person from being happy, from struggling for her happiness. I risked here what would be a smile, as violence interferes with people's happiness, it stops them from being happy (Young person 6); Violence is anything which comes to harm the person, as it affects his well-being, and leaves the person sad (Young person 19); [...] violence leads to sadness, it brings a load of feelings which end in sadness, will bring rage, guilt, frustrations, irritation, which are the feelings which emerge, depending on the type of violence (Young person 16).

Violence harms the young person's wholeness, sometimes stopping them from following their dreams to achieve happiness. It can also constitute a vicious circle, permeated by frustrations, sadness, pain and fear.

In the conception of other young people, violence also impedes happiness because it causes physical, moral and psychological harm. Violence is any action which causes moral, physical or psychological damage, causing unhappiness to third parties or to oneself (Young persons 17 and 21); Violence is everything which harms the physical, mental and social integrity of the human being, and leaves people unhappy (Young person 20).

In considering that violence causes harm in the physical and psychological dimensions of the human being, the young people make a distinction between the physical body and the mental, they fragment the body, and do not conceive of it in its totality. For Merleau-Ponty, the human being needs to be understood as a whole - body, mind, interiority and exteriority, with its biological, psychological and historical constitution, as the body expresses the totality of human existence, and constitutes a set of experienced significations. The body has to be visualized in its interconnections, which occur in the organism, internally, as a system, and externally, in the relations with the environment, the culture and history of each one - and not to dichotomize it in parts. ${ }^{7}$

These young peoples' dichotomized understandings, however, can be better understood when one understands that the culture which these young people are part of, the environment where they live, their experiences and opportunities for accessing education, culture and professional training linked to the biological area can make it possible for them to think about the human being as a dichotomous being: body-mind. It makes it more likely that they will consider the body in parts with or without interference between each other, however, even so, they understand that violence, through provoking physical and psychological harm, leads to unhappiness which, consequently, interferes in their corporeality.

Violence can also be considered an obstacle to the achieving of projects of happiness conceptualized by the young people. Achieving such projects, however, requires each one to take a position regarding herself and the world, as each one's projects for happiness are not something which is finished or planned; they require a constant process of adjustment, un-adjustment, and re-adjustment, as this is part of the condition of being alive and interacting with the world. ${ }^{4}$

The meeting of the young person with situations of violence leads to a process of reflection regarding this phenomenon with a view, however, to seeking elements of an individual and collective character which can instrumentalize her to react. However, for this, the young person needs, in first place, to have knowledge regarding the violence, its typology and nature, in order to have the possibility of recognizing it in her life context and, thus, to create defense and protection mechanisms which viabilize the construction of her projects for happiness. In this context, the parents and the nursing and health professionals, when they meet with the young people, have the task of helping them to construct their projects for happiness, through openness to dialogue and active listening, without judgment, but also without losing the ethical precepts. ${ }^{4}$

This being the case, it is fundamental to plan and discuss with the young person, at all points during the meeting, the paths to be travelled and the choices to be made during their journey, the aim being to investigate the situations of vulnerability to violence in the individual, social and programmatic ambits, and, consequently, to help her to see herself as a citizen with rights, but also duties.

\section{Negligence in the relation between parents and children - a form of violence}

The young person is a being experiencing a stage of human development which is characterized by biological transformations, by her social, intellectual and psychological construction, by conquests, independence from the family, autonomy and affirmation which result in decisionmaking. This is a condition which requires, even 
more, support and care from the parents. If the parents do not offer the support, they may be neglectful and, perhaps, making the young person more susceptible to the action of the violent world which surrounds her.

In discoursing on the issue of violence, the young people emphasize neglect, observed in the lack of care and of limits established by some parents, observed in the following manifestation: violence is what the parents are doing to their children's education [...]. The problem is that the parents are bringing their children up to use drugs. If they let the youngster do anything he wants to, like missing classes to go out with friends, or driving without a license, why shouldn't he smoke marijuana when he wants to? I think that that is violence too, it happens exactly because the parents don't know how to bring up the child not to do that. That's exactly how it is: some parents avoid confronting the problem. For the parents, I think the biggest problem is them pretending that they can't see what is happening with the youngster (Young person 5).

Neglect is considered one of the most serious types of violence, as it interferes, in a devastating way, in the health of children and young people. This type of violence is difficult to define, as it involves cultural, social and situational aspects which can hinder its identification. It involves situations which range from not supplying the basic needs (food, clothes) to lack of tenderness, protection and care. ${ }^{14}$

Considering the discourse of Young person 5 , one can say that the lack of dialogue between parents and children compromises the family dynamic and weakens its bonds, being configured as a vulnerabilizing element, mainly in the individual ambit which is "related to the aspects of cognition, values, experiences and coercion". 5:65 However, it is highlighted that in this stage of the life course, the young person does not yet have sufficient elements to process all the information which she receives, and may have difficulty judging the invitations and opportunities which require decisions to be made, as she is vulnerable on the individual plane, and because of this requires support and guidance from the family.

The young person is a being of relations which can, in her routine, expose her to violence or protect her from it. This confrontation requires a positioning which will be influenced by the knowledge which the young person has regarding violence, its consequences, and her capacity to process this information and transform it into practices which ensure her protection. However, whatever her decision may be, she will accompany the construction of her personal trajectory, with consequences for her present and future life, this being part of her history.

This being the case, over the course of her life, and especially in this stage, her parents need to find ways of overcoming the lack of time which life imposes, and dialogue with their children, aiming to give them the support which they need for the choices which they will make, avoiding neglecting their role in relation to education and care for their children. The young people, in their turn, need limits in order to feel secure, and need to establish a relationship of trust so as to be sure that they can rely on their parents at all times, that they are not alone and unsupported in relation to the decisions which life requires.

Another young person considers violence to be the lack of love, tenderness and care. In this case, neglect can be defined as the parents' or guardians' failure to provide the emotional needs of tenderness, attention and care, and the basic needs which the young person needs in order to grow and develop healthily. Violence [...] can be lack of love, lack of tenderness, lack of attention, lack of care, of money. These are the power relations between parents and children (Young person 4).

The deprivation of tenderness, love and attention - and also of economic conditions - as well as being understood as a form of violence which harms the wholeness of the young person, can also make her a sad being. It can hinder her from following her dreams and seeking happiness, interfering in her corporeality, in her way of being in the world, leading her to make decisions which can lead to crime, perhaps in order to call her parents' attention, or to meet a basic need.

In the current family context, one can observe that the world of work leads the parents to spend more time far from their children, a circumstance which often leads them to blame themselves for this situation, and, in an attempt to fill this gap, many parents end up giving way, letting their children do as they wish, giving them a type of liberty which the youngsters often do not know how to coexist with, or what to do with it.

On the other hand, one can think, regarding the parents' behavior, that this is not a form of negligence, but, rather, that it is a stance, even if unconscious, aimed at avoiding reproducing the power relations of their parents in the past. It may be that this stance adopted by the parents 
is a way of manifesting their attention and love for their children, or of not reproducing the cycle of violence observed over the history of power relations between parents and children. ${ }^{15}$ However, one should not fail to reflect regarding the responsibility which parents have regarding their children, as responsibility is an essential structure, fundamental in order to be constructed in the family, as it facilitates young peoples' decisionmaking in relation to situations of violence and vulnerability.

It is the parents, however, who are responsible for leading the young to have responsibility, and emphasis is placed, again, on the need to establish dialogue with the young person, such that she may be aware of her responsibility for her life and for the life of the people who love her and who coexist with her. The young person needs to think about the construction of the future which differs from what the present reveals, with limits and responsibilities and without violence. Parents and children need to find a point of balance between excessive liberty - which can be transformed into negligence - and the dilution of the power relationships, which can be transformed into relationships of confidence, diligence, care and responsibilization.

\section{Violence in the family relations - situations of vulnerability}

The family is a social unit, a space where people with biological, emotional and affective bonds relate and coexist, which significantly influences young peoples' routine and formative process, giving rise to situations, which may be protected or not, referent to the field of health and illness. ${ }^{16}$

Nowadays, however, it is possible to observe, in the media and in the routine of society, that the majority of cases of violence involving children, adolescents and the young take place in the family ambit, which often hinders the identification and the adopting of immediate stances which avoid further exposure to the trauma.

In their discourses, the young people state that, at some times, the family can be configured as a place of punishment, sadness, suffering, and the promotion of violent practices. Violence is a punishment, mainly when it happens at home, which is the first contact that you have. If you live in a family which is always in conflict, you either close up or you end up becoming a violent person. In this case, the violence is a punishment (Young person 10).
Intrafamily violence contributes to creating situations of vulnerability, as it provokes a disorganization in how the family cares for and protects the young person. Situations of violence in the family environment leave the young person unsupported, vulnerable in the individual plane, as the violence can cause feelings of fear and inferiority, leading to isolation, making the person either an even more susceptible victim, or a violent being.

Acts of violence, when present in the family context, can also make the young person vulnerable in the social ambit. This situation is owed to the fact that intrafamily violence is unlikely to be notified, as the family is considered by society to be a sacred nucleus, which must not be harmed or suffer any type of disloyalty from the people who compose it. In addition to this, intrafamily violence involves many people, whether in the condition of aggressor or accomplice, hindering the intervention of the protection services and making it unlikely that violent acts should be discovered and resolved, which contributes to the growth of a context which should not exist in the family environment. ${ }^{15}$

Other young people understand the violence present in the family context as death, in the symbolic, subjective sense. I related violence to death. Death is bad, and so is violence. Not just physical death, but also as a way of losing love, tenderness and respect, mainly in the family (Young person 8).

Death signifies the end, the end of the "vital journey of a being [...], the end of any journey could be interpreted as a process with a beginning, middle and the end". 17:220 Death, in this young person's conception, can be interpreted as something which annuls the person, and which means losing tenderness, attention, care and respect; death in the sense of denying the young person the pleasure of living and coexisting in a family. Violence, understood as death, is the opposite path to pleasure, disharmonizes corporeality, and impedes the young person from perceiving the happiness and beauty of the world, leaving her unbalanced. In these conditions, the young person loses love, tenderness and, perhaps, the desire to live and relate to the people around her, in particular the family, transforming her into a sad being.

It is emphasized that the main types of violence established in the family environment are physical, psychological, sexual and of neglect; types of violence which cause damage which is sometimes difficult to reverse. Physical violence 
can make a child significantly more aggressive; when children are victims of sexual abuse and neglect they present many psychosocial problems. Children exposed to their parents' violence have depressive events, suicidal behavior, and difficulty in relating to friends and boy/girlfriends. ${ }^{18}$

The violence experienced by the child and adolescent during the process of growth and development can influence violent behaviors in their romantic relationships in youth and adulthood. Besides this, children and adolescents who are victims of family violence can become more susceptible to violence in other environments - at school, in the community, and in romantic relationships. ${ }^{19}$

Even without there being an exact dimension of this phenomenon in the family ambit, one cannot deny that violence in the private space of the family causes devastating and sometimes irreversible harm in the corporeality of each young person, who react in different ways to protect themselves in this brutal context.

Considering the innumerable aspects which try to explain and/or understand the violence present in family relationships, aspects of the theory of vulnerability are sought, ${ }^{5}$ in the individual plane, in order to emphasize that the young person does not have all the necessary conditions to devise strategies which may help her to free herself and/or protect herself from it, as she also has limited capacity to identify it, because violence, often, is disguised in the family context.

In addition to this, the individual behaviors are related to the aspects of cognition, to values and to experiences which influence or define the young person's decisions in relation to the violence suffered. In this situation, one can also observe vulnerability in the social plane, after the point at which society, even knowing about the presence of violence, does little or nothing apart from judging. ${ }^{5}$ This being the case, it is important to use the concept of vulnerability in order to understand the violence which permeates the young peoples' life, as this concept seeks to understand the phenomenon beyond its biological determinants, and is concerned with understanding the dimension of the situations which generate violence, taking into account the multi-causality and its various meanings. ${ }^{20}$

Emphasis is also placed on the relevance of looking at the issue of violence in a broad way, analyzing the various actors. In this way, it is necessary for nursing and health professionals to be familiar with the family context in order to think about support strategies which are appropriate to each situation, ${ }^{21}$ as any type of violence causes harm to young peoples' health, with repercussions in the short and long-term, with consequences which are difficult to measure. For this, it is essential to think about interdepartmental and interdisciplinary actions which seek to identify cultural, social, economic and environmental aspects which can support or perpetuate situations of violence.

\section{FINAL CONSIDERATIONS}

Violence is present in all places, is part of the construction of societies, and is a phenomenon which accompanies the existence of young people, constituting part of their life trajectory. As a result of this, this issue is increasingly meaningful, gaining importance in various areas of knowledge, including health and nursing, because of its scale and the devastating consequences which it provokes in the lives of human beings - in particular the young.

The results reveal that young peoples' understanding regarding violence is influenced by the world they experience, their perceptions, meanings and understandings of the world. The world experienced by the young people is crossed, at various times, by situations of violence present in the family and social relationships.

The understanding regarding violence manifested by the young people, when contextualized with the framework of corporeality and vulnerability, allowed a broad range of significations, making it possible to assert that they are corporeal beings who are vulnerable to violence, in particular, in the individual and social dimensions, in this way expanding the range of interpretation and possible actions which can be considered in order to try to combat this phenomenon which interferes in their way of being in the world.

Among the fundamental points to be emphasized is the creation of healthy environments in the family and social ambits, such that the young person can find appropriate spaces for developing. These environments need to be permeated by tenderness, attention, love, protection and care, elements which promote the development of the young person's capacity to interpret each situation which is presented and to take the appropriate decisions, with the aim of overcoming and coexisting with the facticities of life. 
Parents and nursing and health professionals have the task of helping young people to construct their projects for happiness. For this, it is essential to grasp the social determinants of violence and the meanings of this exposure for the young, so as to plan strategies centered on promoting health, protection and the rehabilitation of young victims of different typologies of violence, triggered in the family and social contexts, with a view to reducing situations of vulnerability to violence.

This research presents limitations; its results cannot be generalized, as they deal with violence experienced and perceived by the young people studied based on the world they experience. However, it presents support for thinking about violence in the young peoples' world, its determinants, its interrelations with their way of being in the world, their cultural, educational and economic resources, as well as the harm resulting from it.

It is believed that the results of this research may add knowledge in various fields of activity of nursing and health professionals: in teaching, and research, and in care practice scenarios. It is considered that the study revealed elements which made it possible to advance knowledge, through revealing the qualitative and subjective understanding of what they think, of how they perceive, and what the young peoples' experiences are in relation to the violence which they live through. It revealed information which is essential in order to understand the young person as corporeality, as a being who can experience situations of vulnerability to violence in the individual, social and programmatic planes, who needs to be, and feel, that she is cared for by the family and by the health professionals, in order to have the conditions to take decisions and live a healthier life.

It is highlighted that the concerns do not end here. The results presented and discussed in this study make it possible to observe a range of investigations which could be undertaken in order to deepen the understanding of the complexity surrounding violence in its different dimensions of the world experienced by the family, teachers, health professionals and young people who experience other scenarios. However, the results reinforce the need to look at the young in the different spaces in which they circulate and make their history, to care for them, to give them a voice, and to propose actions and health policies which visualize them and understand them as corporeality.

\section{REFERENCES}

1. Reichenheim ME, Souza ER, Moraes CL, Jorge MHPM, Silva CMFP, Minayo MCS. Violence and injuries in Brazil: the effect, progress made, and challenges ahead. Lancet, [online]. 2011 [acesso 2014 Nov 27]; Disponível em: http://www. thelancet.com/journals/lancet/article/PIIS01406736\% 2811\%2960053-6/fulltext\#article_upsell

2. Waiselfisz JJ. Mapa da violência 2012: crianças e adolescentes do Brasil. Rio de Janeiro (RJ); [online]. 2012 [acesso 2013 Nov 11]; Disponível em: http:/ / www.mapadaviolencia.org.br/pdf2012/ MapaViolencia2012_Criancas_e_Adolescentes.pdf

3. Correa CS, Souza SJ. Violência e vulnerabilidades: os jovens e as notícias de jornal. Fractal: Rev Psicol. 2011 Set-Dez; 23(3):461-86.

4. Ayres JR. Organização das ações de atenção à saúde: modelos e práticas. Saúde Soc [online]. 2009 [acesso 2014 Nov 27]; 18(supl2). Disponível em: http:/ / www.scielo.br/pdf/sausoc/v18s2/03.pdf

5. Ayres JRCM. Vulnerabilidade e violência: a resposta social como origem e solução do problema. In: Westphal M, Bydlowski CR. Violência e juventude. São Paulo (SP): Hucitec; 2010. p. 59-71.

6. Bertolozzi MR, Nichiata LYI, Takahashi RF, Ciosak SI, Hino P, Val LF, et al. Os conceitos de vulnerabilidade e adesão na saúde coletiva. Rev Esc Enferm USP. 2009 Dez; 43(Esp2):1326-30.

7. Merleau-Ponty M. Fenomenologia da percepção. $3^{\mathrm{a}}$ ed. São Paulo (SP): Martins Fontes; 2006.

8. Wright LM, Leahey M. Enfermeiras e Famílias: um guia para avaliação e intervenção na família. $5^{a}$ ed. São Paulo (SP): Roca; 2012.

9. Nascimento LC, Dantas IRO, Andrade RD, Mello DF. Genograma e ecomapa: contribuições da enfermagem brasileira. Texto Contexto Enferm [online]. 2014 [acesso 2014 Mai 30]; 23(1). Disponível em: http:/ / www.scielo.br/pdf/tce/v23n1/ pt_0104-0707-tce-23-01-00211.pdf

10. Cabral IE. Uma abordagem criativo-sensível de pesquisar a família. In: Althoff CR, Ingrid E, Nitschke RG. Pesquisando a família: olhares contemporâneos. Florianópolis (SC): Papa-livros; 2004. p.127-139.

11. Ricoeur P. O conflito das interpretações: ensaios de hermenêutica. Rio de Janeiro (RJ): Imago; 1978.

12. Terra MG, Gonçalvez LHT, Santos EKA, Erdmann AL. Fenomenologia-hermenêutica de Paul Ricoeur como referencial metodológico numa pesquisa de ensino em enfermagem. Acta Paul Enferm. [online]. 2009 [acesso 2014 Nov 27]; 22(1):93-9. Disponível em: http://www.scielo.br/pdf/ape/v22n1/a16v22n1. pdf

13. Veenhovem R. Medidas de la felicidad nacional bruta. Intervención Psicosocial. 2009 Dez; 18(3):279-99. 
14. Lobato GR, Moraes CL, Nascimento MC. Desafios da atenção à violência doméstica contra crianças e adolescentes no Programa Saúde da Família em cidade de médio porte do Estado do Rio de Janeiro, Brasil. Cad Saúde Pública [online]. 2012 [acesso 2014 Set 23]; 28(9):1749-58. Disponível em: http:/ / www. scielosp.org/pdf/csp/v28n9/v28n9a13.pdf

15. Souza MKB, Santana JSS. Atenção ao adolescente vítima de violência: participação de gestores municipais de saúde. Ciênc Saúde Coletiva [online]. 2009 [acesso 2014 Nov 27]; 14(2):547-55. Disponível em: http:// www.scielo.br/pdf/csc/v14n2/a23v14n2.pdf

16. Cocco M, Lopes MJM. Violência entre jovens: dinâmicas sociais e situações de vulnerabilidade. Rev Gaúcha Enferm. 2010 Mar; 31(1):151-9.

17. Pisetta EE. Morte e finitude. Síntese - Rev Filosofia. 2007 Mai; 34(109):219-46.
18. Peltonen K, Ellonen N, LarsenHB, Helweg-Larsen K. Parental violence and adolescent mental health. Child Adolesc. Psychiatry. 2010 Nov; 19 (11):813-22.

19. Abranches CD, Assis SG. (In)visibilidade da violência psicológica na infância e adolescência. Cad Saúde Pública. 2011 Mai; 27(5):843-54.

20. Ruotti C, Massa VC, Peres MFT. Vulnerabilidade e violência: uma nova concepção de risco para estudo dos homicídios de jovens. Interface - Comunic, Saúde, Educ. 2011. Abri-Jun; 15(37):377-89.

21. Angelo M, Prado SI, Cruz AC, Ribeiro MO. Vivências de enfermeiros no cuidado de crianças vítimas de violência intrafamiliar: uma análise fenomenológica. Texto Contexto Enferm. [online]. 2013. [acesso 2014 Jan 12]. 22(3) Disponível em http:/ / www.scielo.br/ pdf/tce/v22n3/v22n3a03.pdf 